\title{
Egészségbiztonsági kihívások a XXI. században - dohányipari befolyásolási technikák és a hevített dohánytermékekkel kapcsolatos aggodalmak
}

\author{
Joó Tamás ${ }^{1,2^{*}}$, Cselkó Zsuzsa ${ }^{3}$, Pénzes Melinda ${ }^{4}$ \\ Szerencsés Viktória ${ }^{1}$, Bodrogi József ${ }^{5}$, Kovács Gábor ${ }^{3}$, Nagy Márta $^{3}$, \\ Demjén Tibor ${ }^{6}$, Bogos Krisztina ${ }^{3}$ \\ ${ }^{1}$ Semmelweis Egyetem, Egészségügyi Közszolgálati Kar, Egészségügyi Menedzserképző Központ, \\ Budapest, Magyarország \\ ${ }^{2}$ Semmelweis Egyetem, Mentális Egészségtudományok Doktori Iskola, Budapest, Magyarország \\ ${ }^{3}$ Országos Korányi Pulmonológiai Intézet, Budapest, Magyarország \\ ${ }^{4}$ Semmelweis Egyetem, Általános Orvostudományi Kar, Népegészségtani Intézet, Budapest, Magyarország \\ ${ }^{5}$ Semmelweis Egyetem, Gyógyszerésztudományi Kar, Budapest, Magyarország \\ ${ }^{6}$ Dohányzás vagy Egészség Magyar Alapítvány, Budapest, Magyarország
}

Beérkezett: 2021. 04. 28.; Elfogadva: 2021.06. 02.

\begin{abstract}
Összefoglalás
A dohányzás hazai viszonylatban és globálisan is óriási terheket ró a társadalomra, a gazdaságra és az egyénekre. A COVID-19 járványhelyzetben fontos kiemelni, hogy a jelenleg rendelkezésre álló tudásunk alapján a dohányzás is azon rizikótényezők közé tartozik, melyek növelik a súlyos lefolyású koronavírus-fertőzés kockázatát. Óriási mértékű lobbitevékenység veszi körül a dohányzás területét. A dohányipar a rendelkezésre álló és nyilvánvaló tudományos bizonyítékok ellenére is mindent elkövet annak érdekében, hogy nehezítse a dohányzás leküzdését célzó népegészségügyi intézkedések és törekvések bevezetését és végrehajtását. A dohányipar már a 20. század közepétől kísérletezik alternatív dohánytermékek kifejlesztésével, amellyel ellensúlyozhatja a klasszikus dohánytermékek fogyasztásának visszaesését. Különböző taktikai megoldásokkal, folyamatos innovációval és új típusú dohánytermékek piacra dobásával (pl. hevített) a dohányipar próbálja a hagyományos dohánytermékek csökkenéséből eredő problémáit ellensúlyozni, valamint - a fogyasztókat, döntéshozókat gyakran megtévesztve - a piacukat és az addikciót meg-, illetve fenntartani. Tanulmányunk célja a dohányipari befolyásolási technikákkal összefüggő legfrissebb információk áttekintése mellett a hevített dohánytermékekkel kapcsolatban elérhető tudományos bizonyítékok összefoglalása, valamint a COVID-19 és a dohányzás közötti kapcsolat ismertetése. Jelen áttekintés a PubMed adatbázisban elérhető publikációkon, valamint hazai és nemzetközi tudományos intézetek honlapján közölt összefoglalókon és felméréseken alapul.
\end{abstract}

Kulcsszavak: egészségbiztonság, dohányipari befolyásolás, hevített dohánytermék, COVID-19 


\title{
Health Security Challenges in the 21 st Century - Tobacco Industry Interference and heated tobacco products
}

\author{
Tamás Joó ${ }^{1,2}$, Zsuzsa Cselkó ${ }^{3}$, Melinda Pénzes $^{4}$, Viktória Szerencsés ${ }^{1}$, József Bodrogi ${ }^{5}$, \\ Gábor Kovács ${ }^{3}$, Márta Nagy $^{3}$, Tibor Demjén ${ }^{6}$, Krisztina Bogos ${ }^{3}$ \\ ${ }^{1}$ Health Services Management Training Centre, Faculty of Health and Public Administration, \\ Semmelweis University, Budapest, Hungary \\ ${ }^{2}$ Mental Health Sciences Doctoral School, Semmelweis University, Budapest, Hungary \\ ${ }^{3}$ National Korányi Institute of Pulmonology, Budapest, Hungary \\ ${ }^{4}$ Department of Public Health, Faculty of Medicine, Semmelweis University, Budapest, Hungary \\ ${ }^{5}$ Faculty of Pharmaceutical Sciences, Semmelweis University, Budapest, Hungary \\ ${ }^{6}$ Smoking or Health Hungarian Foundation, Budapest, Hungary
}

\begin{abstract}
Summary
Smoking causes a huge burden on society, economy and individuals, both domestically and globally. During the COVID-19 pandemic, it is important to highlight that, to the best of our current knowledge, smoking is also one of the risk factors that increases the risk of severe coronavirus infection. There are enormous lobbying efforts surrounding the tobacco area. Despite the available and clear scientific evidence, the tobacco industry is doing its utmost to make it more difficult to introduce and implement public health measures and efforts to combat smoking. The tobacco industry has been experimenting with the development of alternative tobacco products since the mid-20th century to offset the decline in consumption of classic tobacco products. Therefore, by using different tactics, the tobacco industry applies continuous innovation and launches new types of tobacco products (e.g. heated), to countervail its problems arising from the decrease of traditional tobacco products, to retain their markets, and to maintain addiction by often misleading consumers and decision-makers. The aims of our study are to review the most recent knowledge about the tobacco industry interference, to summarize available scientific evidence related to heated tobacco products, and to present the current association between COVID-19 and smoking. This review summarizes the existing knowledge based on publications in the PubMed database and on reviews and research data published by national and international scientific institutions.
\end{abstract}

Keywords: health security, tobacco industry interference, heated tobacco products, COVID-19

\section{Bevezetés}

A dohányzás hazai viszonylatban és globálisan is óriási terheket ró a társadalomra, a gazdaságra és az egyénekre is (Joó 2019). Összehasonlításképp látnunk kell, hogy amíg a COVID-19 pandémia következtében 1 év alatt megközelítőleg 2 millió ember vesztette életét, addig minden évben világszerte több mint 8 millió ember halálát okozzák a dohányzással összefüggésbe hozható betegségek (World Health Organization 2019c; Johns Hopkins University). A világjárvány elleni védekezésben a különböző kormányok radikális korlátozó intézkedésekkel léptek fel, amelyeket a társadalom is többé-kevésbé elfogadott. A dohányzás esetében pedig kvázi „legalizált", mindenki számára elfogadott formában zajlik az emberek tömeges függővé tétele, valamint megbetegítése anélkül, hogy radikális korlátozó intézkedésekkel akarnánk megelőzni a világjárványénál négyszer nagyobb tömeges halálozást, nem is szólva a társadalmi-gazdasági következményekről.

Óriási mértékû lobbitevékenység veszi körül a dohányzás-területet. A dohányipar a rendelkezésre álló és nyilvánvaló tudományos bizonyítékok ellenére is mindent elkövet annak érdekében, hogy nehezítse a dohányzás leküzdését célzó közegészségügyi intézkedések és törekvések bevezetését és végrehajtását (Bialous-Glantz 2018). Az iparág jelentős eróforrással és számos kifinomult taktikával igyekszik akadályozni a WHO FCTC (World Health Organization, Framework Convention on Tobacco Control - Egészségügyi Világszervezet, Dohányzás-ellenőrzési Keretegyezménye) rendelkezéseinek átfogó végrehajtását. A dohányipari akadályozás sokféle formát ölthet, de mindegyiknek célja a hatékony dohányzás-ellenőrzési intézkedések gyengítése, aláásása és akadályozása. Egyes tevékenységeket nyíltan folytatnak, másokat burkoltabban. A dohányipar részéról a dohányzás-ellenőrzési erőfeszítések megzavarására általában alkalmazott taktikák a következók (World Health Organization 2019a):

- politikai és jogalkotási folyamat akadályozása, eltérítése;

- az iparág gazdasági jelentőségének eltúlzása (foglalkoztatás, adóbevételek stb.);

- a közvélemény manipulálása a tiszteletreméltóságot sugalló kép kialakítása érdekében;

- lobbitevékenység a döntéshozóknál;

- a már bizonyított tudományos eredmények hiteltelenné tétele, és álhír-buborékok gyártása;

- kormányok megfélemlítése perekkel vagy perrel való fenyegetéssel. 
„Az ellenérdekelt iparági érdekcsoportok - nem válogatva az eszközök között - több országban eredményesen akadályozzák a szigorúbb szabályozás létrejöttét. Főbb érveik sok gazdasági és politikai döntéshozót meghátrálásra sarkallnak: ezek jellemzően a munkahelyek elvesztése, a feketekereskedelem fokozódása, a beruházások és az adóbevételek elmaradása miatti gazdasági veszteség. A meghátrálás annak ellenére történik, hogy a megbetegedések, a betegállomány, vagy akár az onkológiai és szív és érrendszeri kezelések csillagászati költségei és a halálozás következményes gazdasági terhein keresztül a dohányzás fenyegeti a nemzetgazdaság, valamint ezen belül kiemelten a szociális- és egészségügyi ellátórendszerek fenntarthatóságát. Emiatt az egészségbiztonság témakörébe soroljuk azokat a tényezőket is, amelyek egy adott nemzet egészségi állapotát, az ellátórendszer sebezhetőségét, fenntarthatóságát, vagy az ezekkel kapcsolatos szuverén döntéshozatalt és annak befolyásolását érintik." (Szócska-Joó 2017).

A dohányipar például több mint fél évszázada kísérletezik olyan alternatív dohánytermékek kifejlesztésével, amelyekkel ellensúlyozhatja a cigarettafogyasztás visszaesését. Jelenleg a hagyományos dohánytermékeknél jóval kedvezőbb szabályozás alá eső hevített dohánytermékekkel próbálja meg - a kormányzat mellett a társadalmat és a lakosságot gyakran megtévesztve - a piacát és az addikciót meg-, illetve fenntartani.

A fentiek miatt rendkívül fontos, hogy továbbra is szilárd evidenciákkal alátámasztott tudományos eredmények szülessenek. Az ilyen jellegú kutatások ugyanis jelentősen hozzájárulhatnak a dohányiparral szembeni hatékony küzdelemhez, és azt is lehetővé teszik, hogy a döntéshozók tiszta forrásból tudjanak tájékozódni e területen.

Tanulmányunk egyik célja a dohányipari befolyásolási technikákkal összefüggő legfrissebb információk áttekintése mellett a dohányipari taktikák elleni hatékony intézkedések bemutatása. Másik célkitûzésünk a hevített dohánytermékekkel kapcsolatban elérhető tudományos bizonyítékok összefoglalása. Ezen belül áttekintjük a hevített dohánytermékek termékjellemzőit, egészségre gyakorolt hatásukat, valamint a nemzetközi és hazai reklámstratégiákat. Harmadik célkitúzésünk a COVID-19 és a dohányzás közötti kapcsolat rövid áttekintése. Jelen áttekintés a PubMed adatbázisban elérhető publikációkon, valamint hazai és nemzetközi tudományos intézetek honlapján közölt összefoglalókon és felméréseken alapul.

\section{Dohányipari beavatkozások}

A dohányipar régóta szisztematikusan, agresszívan, kitartóan és nagy eróforrásokkal lép fel a dohányellenes intézkedésekkel szemben (World Health Organization 2008b), és akár az életmentő dohányellenes intézkedések ellen is kész lépéseket tenni. Különféle taktikákat alkalmazva akadályozza, késlelteti, gyengíti vagy aláássa a po- litikai döntéshozatalt a dohányellenes intézkedésekkel kapcsolatban. Míg egyes stratégiái a nyilvánosság számára is ismertek, addig mások inkább rejtve maradnak (akár a kormányokat, a nyilvánosságot vagy a médiát célozzák), de mindegyik célja a dohányáruk ellenőrzésének és szabályozásának a gyengítése (World Health Organization 2019c). A dohányipar beavatkozásának megakadályozása kulcsfontosságú a dohányzás okozta globális probléma sikeres megoldásához és a dohányzás népegészségügyi kockázatának csökkentéséhez. Az Egyesült Nemzetek Szervezetének Közgyúlése 2011-ben elismerte a „dohányipar és a közegészségügy közti alapvető érdekellentétet" (UN General Assembly 2011). Ezen egyértelmú, kibékíthetetlen érdekellentét elismerése azt jelenti, hogy a dohányipar folyamatos próbálkozásai ellenére, hogy önmagát legitim partnernek és érdekeltnek állítsa be a dohányáruk ellenőrzése terén, az Egyezményben részes Felek kötelesek teljesíteni az Egészségügyi Világszervezet Dohányzás-ellenőrzési Keretegyezményének 5.3. cikkelyében megszabott kötelezettségeiket, melyek elö́ríák a következőt: „A Felek a dohányáruk ellenőrzésével kapcsolatos közegészségügyi politikáik kialakítása és megvalósítása során kötelesek a nemzeti törvényeknek megfelelően biztosítani azok védelmét a kereskedelmi érdekcsoportokkal és a dohányipar érdekcsoportjaival szemben" (World Health Organization 2003, updated 2004, 2005).

A dohányipar számos taktikája közül érdemes kiemelni, hogy a Foundation for a Smoke-Free World (Alapítvány a Füstmentes Világért) nevű szervezetet kizárólagosan a Philip Morris International (PMI) finanszírozza, évi 80 millió dollárral, 12 éves időtartamra számolva közel 1 milliárd dollárral (Foundation for a Smoke-Free World 2018; World Health Organization 2019c). A tudományos és politikai programok befolyásolása az iparág aktuális stratégiájának részét képezik. Az Alapítvány olyan kutatási programokat és tanulmányokat finanszíroz, melyek támogatják a PMI és más gyártók által forgalmazott termékek „csökkentett kockázatúnak” történő beállítását, illetve támogatást ígér azon kormányoknak, egyetemeknek, ENSZ-ügynökségeknek, egyéb nemzetközi szerveknek és népegészségügyi szakértők közösségeinek, melyek bátorítják a dohányzókat a kérdéses termékek használatára, feltehetőleg a hagyományos cigaretták helyében. 2017 szeptemberében az Egészségügyi Világszervezet hivatalos közleményt adott ki, mely szerint nem vállal partneri kapcsolatot az Alapítvánnyal, és javasolja, hogy a kormányzatok és a népegészségügyi szakemberek közösségei is így járjanak el (World Health Organization 2017b). Az Egészségügyi Világszervezet Dohányzás-ellenőrzési Keretegyezményének Titkársága hasonlóképpen egyenes módon utasította el az Alapítványt, hivatalos nyilatkozatában megállapítva, hogy az Alapítvány a Füstmentes Világért egyértelmú próbálkozás az Egészségügyi Világszervezet Dohányzás-ellenőrzési Keretegyezményének a közpolitika befolyásolása általi megsértésére, „azzal a céllal, hogy károsítsák az 
egyezmény megvalósítását, különösképp az alapítvány rosszhiszemú kutatási programjai által" (World Health Organization 2017a). A fentieket követően, 2019-ben az Alapítvány írt az Egészségügyi Világszervezet Igazgatótanácsának, felkérve a szervezetet, hogy módosítsa az Alapítvánnyal kapcsolatos álláspontját, és hogy „vizsgálja felül és gondolja át, hogyan érdemes a legjobban együttmúködni az Alapítvánnyal a veszélyes cigaretták használatának gyors csökkentésének elősegítésében”. Ezt a javaslatot a WHO fóigazgatója - aki 2017-es nyilatkozatában megerősítette az Egészségügyi Világszervezet álláspontját - elutasította (World Health Organization 2019b).

\section{Dohányipari taktikák elleni védelem}

2008-ban az Egészségügyi Világszervezet Dohányzásellenőrzési Keretegyezményében részes Felek Konferenciája elfogadta az 5.3. cikkely megvalósítására szolgáló irányelveket. Az Irányelvek a tudományos bizonyítékok és a Felek tapasztalatai alapján lettek kidolgozva (World Health Organization 2008a). Az Irányelvek célja „biztosítani, hogy a dohányzásellenes intézkedések kereskedelmi és egyéb dohányipari érdekcsoportokkal szembeni védelme átfogó és hatékony legyen”. Világosan kimondják, hogy a kormányzatoknak korlátozniuk kell a dohányiparral való interakcióikat, kerülniük kell a partneri kapcsolatokat, valamint a kormányzatok nem fogadhatnak el pénzügyi vagy más támogatást a dohányipartól, vagy az annak érdekében eljáró felektől. Az Irányelvek továbbra is hozzájárulnak a dohányipar befolyásolási kísérleteivel szemben folytatott harchoz, és alkalmazandók minden olyan hagyományos és fejlődő dohánypiacra, ahol a dohányipar megkísérli magát partnerként feltüntetni a dohánytermékek ellenőrzésében és a veszélyek mérséklésében, miközben ugyanakkor a szabályozási törekvéseket is akadályozza.

További hatékony és az Egészségügyi Világszervezet által javasolt kormányzati intézkedések lehetnek a dohányipar beavatkozásai ellen például a következők (World Health Organization 2019c):

- „a hevített dohánytermékeket dohánytermékekként szabályozni;

- megkövetelni a kutatóintézmények, tudományos szervezetek, tudományos tanulmányok támogatási forrásainak bevallását és egyértelmú kommunikációját, így megakadályozva az észrevétlen elfogultságot az olyan tudományos munkákban, melyekre a szakpolitika alapozhat, illetve megkövetelni a nem kormányzati szervezetektől, vállalatoktól és kereskedelmi szövetségektől, fogyasztói csoportoktól, elemzőközpontoktól, szakmai szervezetektől és más, a dohányellenes politikákban részt venni vagy azokhoz hozzájárulni kívánó felektől, hogy tisztázzák motivációikat;

- dohányiparral való partneri és üzleti kapcsolatok kerülése;
- tudatosítani a lakossággal a dohány és a nikotint tartalmazó termékek ismert függőséget okozó és ártalmas hatásait, illetve a dohányipar dohányellenes intézkedésekbe való beavatkozásait;

- denormalizálni és a lehető legnagyobb mértékben szabályozni a dohányipar által »társadalmi felelősségvállalásnak « nevezett tevékenységeket és betiltani az azokhoz füződő bujtatott reklámozást;

- megkövetelni a dohányipar felelősségre vonását a marketingkampányok során bemutatott megtévesztő információk kapcsán;

- megkövetelni a dohányipar által megadott információk átláthatóságát és pontosságát, illetve rendszeres, valós, teljes és pontos információt követelni a dohányipar tevékenységeiról;

- bevezetni és érvényesíteni egy a dohányellenes intézkedések kidolgozásán, megvalósításán és betartatásán dolgozó törvényhozókra és tisztviselőkre érvényes hatékony összeférhetetlenségi politikát;

- ismételten és évente át kell tekinteni minden részes országban a 2004-ben elfogadott és azt követően ratifikált, WHO Dohányzás-ellenőrzési Keretegyezmény pontjainak betartását”.

\section{Hevített dohánytermékek}

Összefoglaló közleményünkben a hevített dohánytermékekkel kapcsolatos fejezet az Egészségügyi Szakmai Kollégium Tüdőgyógyászat Tagozatának 2019-es állásfoglalásán alapul, kiegészítve azt a legfrissebb kutatási eredményekkel és hivatkozásokkal. „A hevített dohánytermékek olyan dohánytermékek, amelyek a dohány hevítésekor vagy egy dohányt tartalmazó készülék aktiválásakor nikotint és mérgező vegyületeket tartalmazó aeroszolt termelnek. Példák ezekre a Japan Tobacco International által gyártott Ploom, a British American Tobacco által gyártott Glo, a PaX Labs által gyártott PaX és a Philip Morris International által gyártott iQOS termékek (World Health Organization 2019c). Az aeroszolt a felhasználók az eszközt szívva vagy szipkázva lélegzik be. Az eszköz által előállított pára, a függőséget okozó nikotin mellett adalékanyagokat és gyakran ízesítóket is tartalmaz (Magyar Tüdögyógyász Társaság 2019).”

A hevített dohánytermékek múködési elve a dohánylevelek égésénél alacsonyabb hőfokra való hevítésén alapul (Jiang et al. 2018). A dohány hevítésére alapvetően négyféle módszert alkalmaznak. Az egyik szerint, a cigarettaszerü termék egyik végén préselt szén töltet található, amelyet a hagyományos cigarettához hasonlóan lehet meggyújtani. Meggyújtás után, a keletkező hő egy közvetítő anyag segítségével érintkezik a dohánytöltettel és képződik a nikotintartalmú aeroszol. Ez a típus nem alkalmaz elektronikus alkatrészeket. Használat után a terméket a hagyományos cigarettához hasonlóan kell eloltani, és kidobható. Egy másik módszer szerint a cigarettánál kisebb méretú, propilén-glikolba mártott dohányrúd helyezhető egy henger alakú eszközbe, 
amelyben akkumulátor és egy fütőelem segítségével hevítődik a dohány. A hevítés hőmérséklete általában 300$350{ }^{\circ} \mathrm{C}$ alatt marad és a dohányfüstnél kevésbé összetett aeroszol képződik. A harmadik módszer szerint egy akkumulátor segítségével füthető kamrában hevítődik a belehelyezett dohánylevél (vagy más szárított növény), majd szívás hatására a képződött aeroszol keveredik a víz és glicerin elegyével, és porlasztással belélegezhetővé válik. Negyedik típusként léteznek úgynevezett hibrid készülékek (elektronikus cigarettaszerú felépítés), amelyek nikotintartalmú folyadékot és dohányt is tartalmaznak. A folyadékból képződő aeroszol átdiffundál a dohánytölteten, miközben hevíti azt és a dohányösszetevőket is tartalmazó aeroszolt ezután lélegzi be a felhasználó (World Health Organization 2020b).

\section{Hevitett dobánytermékekkel kapcsolatos marketing és használati szokások}

A hevített dohánytermékek népszerüsítését célzó reklámstratégia eleget tesz a modern kor technikai igényeinek és az ártalomcsökkentésre vonatkozó elvárásoknak. Az ügyesen felépített marketingstratégia része, hogy egyes hevített dohánytermék-értékesítőhelyek kialakítása hasonlít a jelenleg népszerű okos készülékeket forgalmazó üzletekre. A hevített dohánytermékeket modern, csúcstechnológiás, felső kategóriás termékekként reklámozzák. Az eszközök minimalista kialakítása, vezető üzletekben való jelenléte és széles körben reklámozott termékbevezetései miatt vonzó és ártalmatlan fogyasztói luxuscikként ábrázolódnak (Jackler et al. 2020). Ezek a törekvések ugyanazon társadalmi pozicionálási technikákat alkalmazzák, melyekkel korábban a cigarettákat forgalmazták, és melyek kifejezetten hatékonyan célozzák meg a fiatalokat (World Health Organization 2019c). A rendelkezésre álló ismeretek szerint a hevített dohánytermékeket jelenlegi vagy leszokott dohányzók használják nagyobb arányban (Bialous-Glantz 2018), azonban a termék vonzóvá válhat a technikai újdonságokra és ízesített dohánytermékekre nyitott nemdohányzó fiatalok számára is (Ratajczak et al. 2020). A 18 év feletti magyar dohányzók 2\%-a használ hevített dohánytermékeket, a használat aránya legnagyobb a 18-34 év közötti nók körében (3\%) (Országos Korányi Pulmonológiai Intézet 2019). Egyelőre nincsenek hosszú távú adatok a magyar lakosság hevített dohánytermék-használatára vonatkozóan. Komoly gondot jelent azonban, hogy miközben a hagyományos dohánytermékek fogyasztása Magyarországon nem az elvárt ütemben csökken, az új típusú nikotintartalmú és dohánytermékek világszerte, így hazánkban is terjednek (Cselkó et al. 2021).

A hevített dohánytermékekre alkalmazott „füstmentes” elnevezés arra utal, hogy az elóállított aeroszol nem tartalmaz kátrányt, míg a „módosított kockázatú dohánytermék" megjelölés pedig csökkentett rizikót feltételező alternatív dohányzást kínál (World Health Organization 2019c). A dohányipar marketingstratégiája az, hogy a hagyományos cigarettához képest a hevített dohánytermékeket kevésbé károsnak állítja be, és erre hivatkozva szorgalmazza a fogyasztást az „egészséges” alternatívát kereső dohányzók körében, illetve igyekszik elkerülni a dohánytermékekre alkalmazott forgalmazási korlátozásokat. A hevített dohánytermékek által előállított aeroszol összetételét és tulajdonságait illetően azonban nem megalapozottak azok az állítások, miszerint ezek a dohánytermékek kevésbé károsak volnának, mint a hagyományos cigaretta (Bialous-Glantz 2018; Simonavicius et al. 2019). Az Egészségügyi Világszervezet közleményben hangsúlyozta, hogy az Amerikai Egyesült Államok (USA) Élelmiszer- és Gyógyszerengedélyeztetési Hivatala (Food and Drug Administration - FDA) azon döntése, miszerint az IQOS márkájú hevített dohánytermék az USA-ban azzal az állítással kerülhet forgalomba, hogy az kevesebb káros és esetlegesen káros vegyületet állít elő, nem jelenti azt, hogy a termék kevésbé káros volna, mint más dohánytermékek, illetve nem jelenthető ki, hogy használatával csökkenthető az egészségkárosodás kockázata. Az ártalomcsökkentő megnevezés tehát nem helyénvaló, sőt a lakosság megtévesztésére alkalmas (World Health Organization 2020a; 2020c).

\section{Hevitett dohánytermékek fogyasztásának hatása az egészségre}

A hevített dohánytermékek által előállított vegyületek közül egyes, úgynevezett káros és esetlegesen káros vegyületek ugyan kisebb mennyiségben vannak jelen, mint a hagyományos cigaretta égésekor keletkező füstben, ugyanakkor mások - amelyek között számos mérgező és rákkeltő is van, nagyobb mennyiségben találhatók. A Nemzetközi Rákkutató Ügynökség (IARC) által az emberre veszélyes rákkeltő anyagokként osztályozott két dohányspecifikus nitrózamin (TSNA), az N'-nitrozonornikotint (NNN) és a 4- (metilnitro-amino) -1(3-piridil) 1-butanont (NNK) előfordulása már $100{ }^{\circ} \mathrm{C}$ on mérhető az aeroszolban. Másik két vegyület, a NAT (N-nitrózoanatabin) és a NAB (N-nitrózoanabazin) $140{ }^{\circ} \mathrm{C}$ felett volt kimutatható. Több olyan vegyület is előfordul továbbá a képződő aeroszolban, amely a hagyományos cigaretta füstjében nem. Ezek az e-cigarettához hasonlóan, az ízesítő adalékanyagokból és az oldószerből származnak és hevítés hatására mérgező vegyületekké alakulhatnak (pl. formaldehid, acetaldehid, akrolein) (St.Helen et al. 2018; Farsalinos et al. 2018; Lempert-Glantz 2020). Fontos kiemelni, hogy az érintett anyagoknál zéró tolerancia van, tehát esetükben nem érvényes az, hogy a kevesebb az jobb. Vagyis a hevített dohánytermékekkel és az e-cigarettával a szervezetbe juttatott, esetleg kevesebb számú rákkeltő anyag ugyanúgy káros, mint a hagyományos cigaretta füstjével bejutó több ilyen anyag.

Egyelőre nem állnak rendelkezésre olyan vizsgálatok, amelyekre alapozva megállapítható a hevített dohánytermékeknek az egészségre gyakorolt rövid és hosszú távú 
hatása. Az eddigi laboratóriumi és klinikai vizsgálatok alapján feltételezhető, hogy a hagyományos cigarettához hasonlóan károsítják a tüdőt, az immunrendszert és az érrendszert. A közelmúltból származó vizsgálatokból ismert, hogy a hevített dohánytermékek szabadgyökök képződésén keresztül károsíthatják a tüdősejteket, amely hozzájárulhat az asztma és a krónikus obstruktív tüdőbetegség kialakulásához (Kopa-Pawliczak 2020; Lee et al. 2019). Összefüggést mutattak ki továbbá a hevített dohánytermékek használata és az allergiás megbetegedések (asztma, szénanátha és atópiás ekcéma) előfordulási gyakorisága között (Lee et al. 2019). A hagyományos dohánytermékeknek hevítettre cserélése nem javítja a tüdő múködését és nem enyhíti a gyulladásos állapotot (KopaPawliczak 2020; Breathe 2020). Mivel a daganatok kialakulásához hosszabb időre van szükség, mint a szív- és érrendszeri, illetve a légzőszervi károsodásokhoz, az eddigi vizsgálatok alapján nem lehet következtetni a hevített dohánytermékek daganatkeltő hatásának mértékére. $\mathrm{Az}$ aeroszolban lévő egyes rákkeltő vegyületek szintje alacsonyabb ugyan, mint a hagyományos cigaretta füstjében mért érték, az alacsonyabb expozíciós szint ugyanakkor nem jelenti azt, hogy ezzel arányosan alacsonyabb lenne a daganatkeltő kockázat, mivel a rák kialakulásának valószínúségét egyaránt befolyásolja, hogy mennyi rákkeltő vegyület jut a szervezetbe, és az milyen hosszan van kitéve ezek egészségkárosító hatásának. A hevített dohánytermék múködése alatt a környezet is exponálódik az aeroszol által, amely nagyszámú illékony szerves vegyületet (VOC), policiklusos aromás szénhidrogént (PAH) és ultrafinom részecskéket tartalmaz (Kopa-Pawliczak 2020). A népegészségügyi követelmények alapján a másodlagos dohányzásnak nincs biztonságos vagy elfogadható szintje (Lal et al. 2018; Moazed et al. 2018).

A dohányzás káros hatásainak mérséklése, azaz a dohányzás visszaszorítása népegészségügyi célkitűzés. A kisebb mértékű, de bizonyítottan jelen lévő egészségkárosító hatása mellett a hevített dohánytermékek a fizikai függőségen kívül a lelki függőséget is megerősítik a rágyújtás és a „cigarettázás” folyamatának napi többszöri ismétlődésével. Az ártalomcsökkentő elnevezés tehát nem helyénvaló, mivel a hevített dohánytermékek egyéni és társadalmi szinten is növelik a dohányzás betegségterhét, szemben a nem dohányzással (Lempert-Glantz 2020). A hevített dohánytermékek már ismert és még ismeretlen egészségkárosító hatásai arra utalnak, hogy használatának elterjedése határozottan ellentétes a népegészségügy céljaival, amely az egészségre ártalmas szerek és eszközök korlátozásával, a szűrővizsgálatokkal, a betegségek megelőzése és korai felismerése révén, az egészséges életmód népszerűsítésével igyekszik megvalósítani az ártalomcsökkentést (Magyar Tüdögyógyász Társaság 2019).

A dohányzók több mint harmada szeretne leszokni (Országos Korányi Pulmonológiai Intézet 2019), nincs azonban bizonyíték arra, hogy a hevített dohánytermékek segítenék a leszokást, sőt nikotintartalmuk révén fenntartják a nikotinfüggőséget. A hagyományos dohánytermékekkel való együttes használat sem zárható ki, és ilyenkor az ártalom nem csökken, sőt a hevített dohánytermék használata károsan befolyásolhatja a végleges leszokás folyamatát (ERS Tobacco Control Committee 2019; Lempert-Glantz 2020). A leszokásra motivált dohányzónak célszerű szakértői segítséget kérnie valamelyik dohányzásról való leszokást támogató programban (telefonos, egyéni, illetve csoportos foglalkozás).

Az Egészségügyi Világszervezet álláspontjára (World Health Organization 2019c) alapozott Tüdögyógyász Tagozati állásfoglalás a hevitett dohánytermékekkel kapcsolatban (Magyar Tüdögyógyász Társaság 2019):

- „A hevített dohánytermékek dohányt tartalmaznak és dohánytermékekként is kell szabályozni őket.

- A hevített dohánytermékek dohánytermékeknek minősülnek. Ez azt jelenti, hogy a tagországok számára az Egészségügyi Világszervezet Dohányzás-ellenőrzési Keretegyezményében megszabott kötelezettségei a hevített dohánytermékekre ugyanúgy érvényesek, mint a hagyományos dohánytermékekre.

- Korlátozni kell a hevített dohánytermékek reklámozását, promócióját és szponzorálását, mivel ez a dohányzás társadalmi elfogadását támogathatja. A hevített dohánytermékek elterjedése fiatalok körében aláshatja azt a küzdelmet, amely az elmúlt évtizedekben a dohányzás társadalmi elutasításáért és a fiatalok dohányzása ellen folyt.

- A hagyományos dohánytermékekről a hevített dohánytermékekre való átállás nem tekinthető leszokásnak. Ebben az összefüggésben felmerül a kockázata annak, hogy a dohányipar „leszokásra” vagy „átállásra" fókuszáló marketingstratégiái következtében a fogyasztók és a döntéshozók összekeverik a két fogalmat.

- A passzív dohányzáshoz hasonlóan, a hevített dohánytermékek által előállított aeroszolt passzívan elszenvedők is ki vannak téve az egészségkárosító vegyületek hatásának.

- Bár a hevített dohánytermékekben megtalálható egyes mérgező és rákkeltő vegyületek szintje alacsonyabb, mint a hagyományos dohánytermékek esetében, más vegyületeket nagyobb mennyiségben tartalmaznak. Az, hogy egyes mérgező vegyületekből kevesebbet tartalmaznak, nem feltétlenül jelenti, hogy kisebb egészségügyi kockázattal jár a fogyasztásuk.

- A hevített dohánytermékek nikotint tartalmaznak. A nikotin erôs függőséget és egészségkárosodást okoz. Kiemelendő a nikotinnak és származékainak az érelmeszesedés, az inzulinrezisztencia, illetve a daganatos betegségek kialakulásában és előmozdításában betöltött szerepe. Ismert a nikotin káros hatása a termékenységre és a magzati fejlődésre, továbbá az is, hogy a magzatként vagy gyermekkorban elszenvedett nikotinexpozíció hozzájárulhat a fiatalkori viselkedészavarok, hangulatzavarok és függőségek kialakulásához. A hevített dohánytermékek különösen kerülendők a 
gyerekek, a serdülők, a várandósok és a nemdohányzók által.

- A hagyományos, a hevített és a füst nélküli dohánytermékek (rágódohány, orron, vagy szájon át fogyasztható dohánytermékek) egyaránt függőséget okoznak és rákkeltők. A dohányzás visszaszorításában és a leszokás támogatásban csak a bizonyított módszerek alkalmazásának van létjogosultsága."

\section{Hevitett dohánytermék magyarországi helyzete}

Magyarországon jelenleg egy típusú hevített dohánytermék érhető el a kereskedelmi forgalomban 2019 áprilisa óta. A hevített dohánytermékek már a piacra lépésük évében számos előnyt élveztek a hagyományos dohánytermékekhez képest. A nemzeti dohányboltokban kiemelt megjelenési lehetőséget (kivilágított kisablak) biztosítottak számukra, valamint „akciós” vásárlási lehetőséget is (ha valaki 2 IQOS-t vesz, akcióban részesül). A dohányrudak többfajta erősségben és ízesítésben (pl. mentolos) kaphatók. Érdemes megjegyezni, hogy a mentolos ízesítést hagyományos dohánytermékek esetén egy EU-s direktíva 2020-tól betiltotta (Directive 2014/40/EU 2014). Képes egészségvédő feliratokat jelenleg nem tartalmaz a hevített dohánytermékek csomagolása, mivel nem vonatkozik rájuk a jogszabály. Mindemellett jelentős adóelőnye van a hagyományos dohánytermékekhez képest, ami miatt az állam évról évre több tízmilliárdos adóbevételtől esik el. Hevített dohánytermék vásárlásakor „kötelező” jelleggel meg kell adni a vevő e-mail-címét, lakcímét és mobiltelefonszámát, amivel egyból beléptetnek mindenkit az IQOS Clubba és a vásárlást követő időszakban mobilon, valamint e-mailben keresik a fogyasztókat, illetve a lakcímre ajándékot küldenek nekik.

A hevített dohánytermékekkel kapcsolatban rendkívül magas közösségimédia-aktivitás figyelhető meg, és sorra jönnek létre zárt használói csoportok. Emellett jelentős online és offline médiajelenlét tapasztalható a füstmentes technológiákkal kapcsolatban. Az Observer Médiafigyelő Kft. által biztosított adatokból elvégzett saját számítá- sok alapján látható, hogy a hevített dohánytermékek 2019-es magyarországi megjelenése óta elárasztotta a (PMI) a hazai online és offline médiát is a füstmentes termékeket és a füstmentes jövőt vizionáló cikkekkel. A PMI a következő megjegyzésekkel látja el ezeket a közleményeket: „A cikk társadalmi felvilágosítás céljából, reklámnak nem minősülő tájékoztatásként készült.”, „A cikk társadalmi felvilágosítás céljából létrejött, reklámcélokat nem szolgáló tájékoztatás.”, és „Ez a tartalom társadalmi felvilágosítás céljából létrejött, reklámcélokat nem szolgáló tájékoztatás." 2019. február és 2020. szeptember között 330 ilyen cikk jelent meg a különböző felületeken, összesen megközelítőleg 6 milliós elérést produkálva. Kiemelendő a COVID „home-office és online" időszak erőteljes aktivitása (1. ábra).

\section{COVID-19 és dohányzás}

A dohányzás mint káros szenvedély és az ipar által végzett káros marketing- és lobbitevékenység különösen veszélyes a mostani járványidőszakban, mivel a jelenleg rendelkezésre álló tudásunk alapján a dohányzás is azon rizikótényezők közé tartozik, melyek növelik a súlyos lefolyású koronavírus-fertőzés kockázatát. A WHO már 2020 júniusában közzétett egy összefoglalót a dohányzás és a COVID-19 kapcsolatáról. Az összegzés 34, a COVID-19 fertőzés és a dohányzás mint betegséget befolyásoló tényező kapcsolatát vizsgáló tanulmány eredményein alapul. Az elérhető tudományos vizsgálatok alapján arra a következtetésre jutottak, hogy a dohányzás összefüggésben van a kórházi kezelésre szoruló COVID-19 betegeknél a betegség fokozott súlyosságával és halálos kimenetelével (World Health Organization 2020a).

A témával kapcsolatos tudományos kutatások azóta még tovább bővültek, és megerősítik, hogy a koronavírusos betegek körében magasabb arányban alakul ki súlyos lefolyású COVID-19 megbetegedés azoknál, akik dohányoztak, mint a nemdohányzóknál. Egy 19 tudományos cikk metaanalízisét bemutató tanulmány eredményei alapján a koronavírusos dohányosok 29,8\%-ánál

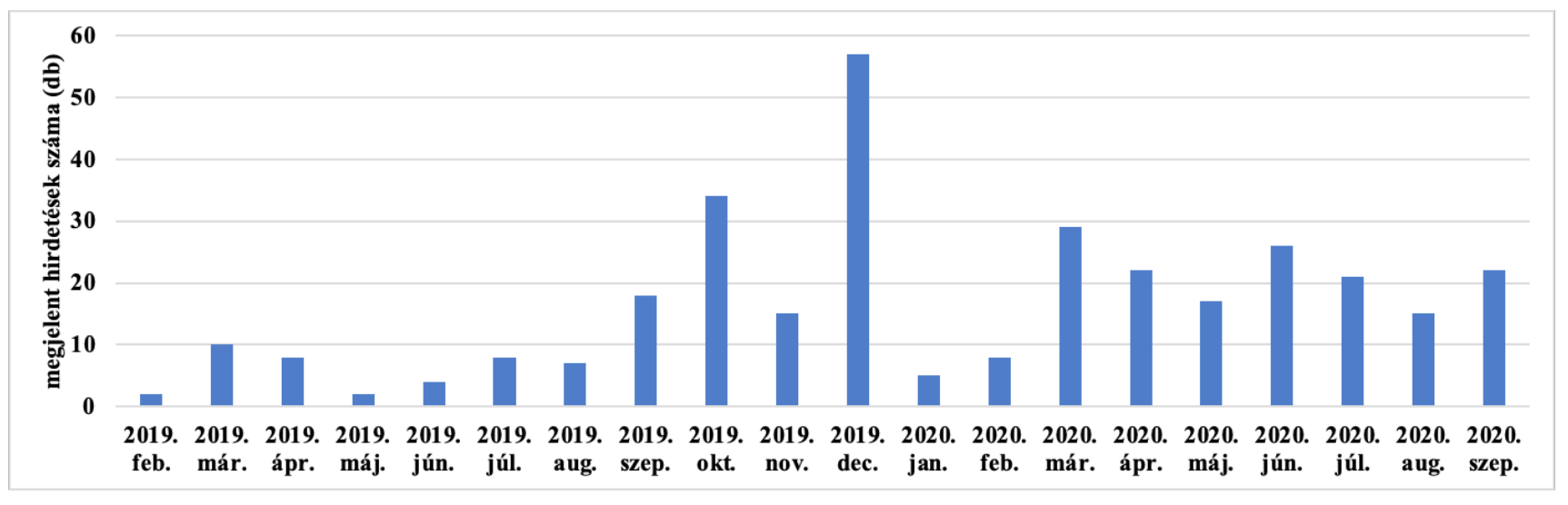

\begin{tabular}{l|l} 
1. ábra & A Philip Morris International füstmentes technológiákkal kapcsolatos online-offline médiamegjelenések száma
\end{tabular} 
alakult ki kezelést igénylő betegség, szemben a nemdohányzók körében tapasztalt 17,6\%-kal (PatanavanichGlantz 2020). Továbbá több vizsgálat is megállapította, hogy a dohányzók körében magasabb az intenzív ellátásra szorulók száma és a halálozási arány is. Fontos azonban hangsúlyozni, hogy még nem áll rendelkezésre elég adat és vizsgálat arra a kérdésre vonatkozóan, hogy magasabb-e az új típusú koronavírus fertőzés incidenciája a dohányosok, mint a nem dohányosok körében (Shastri et al. 2021).

Hazánkban is foglalkoznak a COVID-19 és a dohányzás kapcsolatával. Az Emberi Erőforrások Minisztériuma már 2020 májusában kiadott egy állásfoglalást, melyben felhívják a figyelmet a dohányzás és a koronavírus súlyos, intenzív osztályos ellátást is szükségessé tevő lefolyása közötti kapcsolatra (Emberi Erőforrások Minisztériuma 2020).

Fontos kiemelni, hogy nem csupán a dohányzás és a COVID-19 megbetegedés kialakulása és súlyossága között van összefüggés, de a dohányzás okozta krónikus megbetegedésekben (COPD, hipertónia, érelmeszesedés stb.) szenvedő idősebb betegek között a legnagyobb arányú a COVID-19 halálozás (Koronavirus tájékoztató oldal 2020).

Számos közlemény jelent meg azzal kapcsolatban, hogy a COVID-19 betegek között alacsony a dohányzók aránya és a kutatásokra épített médiaaktivitások középpontjába került, hogy a dohányzók védettek lehetnek a SARS-CoV-2-fertőzés ellen. Egy átfogó közlemény azonban rávilágít arra a folyamatra, amelynek eredményeként a tudósok és a média teljesen félreértelmezte a kutatásokat. Felhívja a figyelmet azok módszertani hibáira is, amelyek elhamarkodott következtetéseken alapultak. A kifogásolt kutatások esetében jellemző módszertani hiba volt a nem megfelelő dohányzói kategóriába sorolás. A SARS-CoV-2-vírussal fertőzött betegek sok esetben olyan rossz állapotban kerültek kórházba, hogy az anamnézis felvétel nem tért ki a dohányzói státuszra, így ezek sokszor ,ismeretlen” vagy „soha nem dohányzó" kategóriába kerültek. Más kutatások esetében nem volt kellő alapossággal meghatározva a leszokott kategória, ezért akár az is leszokott dohányzónak számított, aki csak a COVID-19 betegség tüneteinek jelentkezésekor - a megkérdezés előtti egy-két napban - hagyta abba a dohányzást. További módszertani hibákat okoztak a nem megfelelő beválogatási és kizárási kritériumok, úgymint az egészségügyi dolgozók felülreprezentálása, vagy a súlyos állapotú betegek kizárása (van Westen-Lagerweij et al. 2021).

A koronavírusokat illetően a dohányzás bizonyítottan fokozza a MERS-CoV-fertőzés kockázatát és a mortalitást. Bár a SARS-CoV-2 esetében - az alacsony mintaszám miatti esetleges zavaró változók kizárásának hiányában - még nem sikerült egyértelmúen igazolni, hogy a dohányzók nagyobb eséllyel fertőződnek, bizonyított, hogy leszokott és aktuálisan dohányzók esetében is emelkedett az angiotenzin-konvertáló enzim-2 (ACE-2) előfordulása a tüdőszövetben, amelyrôl kiderült, hogy a SARS-CoV és a SARS-CoV-2 receptora (Reddy et al. 2020). Egyes vizsgálatok szerint az ACE-2 fokozott elöfordulása mögött meghúzódó komplex biokémiai folyamatokat a nikotin is beindíthatja (Russo et al. 2020). Összességében tehát úgy tứnik, hogy a dohányzás különböző mechanizmusok útján nemcsak a COVID-19 iránti fogékonyságot növeli, hanem a betegség lefolyását is súlyosbíthatja (Gupta-Nethan-Mehrotra 2021).

\section{Összegzés}

Magyarország 2010-2014 között nagyot lépett előre a dohányzás visszaszorítását célzó küzdelemben. Számos pozitív intézkedést sikerült bevezetni: a dohányzás zárt légterü közforgalmú helyeken történő teljes tiltása, képes egészségvédő feliratok megjelenése a dohánytermékeken, többszöri jövedéki adóemelések, kiskereskedelmi rendszer átalakítása, a megelőzés terén történt fejlesztések, a dohányzásról leszokást támogató intézményrendszer erósítése, amelyek mind hozzájárultak a dohányzás prevalencia és a dohányfogyasztás mérséklődéséhez (Joó et al. 2017; Joó et al. 2018).

Mindezek ellenére a dohányzás még mindig jelentős egészségügyi, társadalmi és gazdasági károk okozója, tehát a fogyasztás visszaszorításának valamennyi technikája és módszere támogatandó. Emellett kiemelendő, hogy óriási mértékủ lobbitevékenység veszi körül a területet. A dohányipar a rendelkezésre álló és nyilvánvaló tudományos bizonyítékok ellenére is mindent elkövet annak érdekében, hogy nehezítse a dohányzás leküzdését célzó népegészségügyi intézkedések és törekvések bevezetését és végrehajtását. A dohányipar beavatkozásának megakadályozása kulcsfontosságú a dohányzás okozta globális probléma sikeres megoldásához és a dohányhasználat népegészségügyi hatásainak csökkentéséhez. E teljes mértékben megelőzhető járvány megfékezésének a népegészségügyi prioritások első helyén kell továbbra is szerepelnie, amely biztosítható a jogszabályok betartásának ellenőrzésével, a dohányzásról leszokás támogatásával, a rászokás megelőzésével, további jövedéki adóemelésekkel, valamint különösen kiemelt fontossággal az új típusú dohánytermékek (kiemelten a hevített dohánytermék) sajátos hazai jelenségével szembeni határozottabb fellépéssel.

\section{Irodalomjegyzék}

Bialous, S. A., \& Glantz, S. A. (2018) Heated tobacco products: another tobacco industry global strategy to slow progress in tobacco control. Tobacco Control, Vol. 27. Suppl. 1. pp. 1-7. DOI: 10.1136/tobaccocontrol-2018-054340

Cselkó, Z., Fényes, M., Csányi, P., Bogos, K., Kiss, J., \& Demjén, T. (2021) Dohányzási szokások és leszokástámogatási feladatok Magyarországon. 1. rész. Lege Artis Medicinae, Vol. 31. No. 3-4. pp. 99-106. DOI: 10.33616/lam.31.006

Directive 2014/40/EU of the European Parliament and of the Council of 3 April 2014 on the approximation of the laws, regulations 
and administrative provisions of the Member States concerning the manufacture, presentation and sale of tobacco and related products and repealing Directive 2001/37/EC. Official Journal of the European Union (2014) Vol. 127. No. 1. pp. 1-38. https://eur-lex. europa.eu/legal-content/EN/TXT/?uri=OJ\%3AJOL_2014_127 _R_0001. [Letöltve: 2021.04.21.]

Emberi Erőforrások Minisztériuma (2020) Milyen veszélye van a járvány idején a dohányzásnak és az elektronikus cigaretta használatnak? https://koronavirus.gov.hu/sites/default/files/sites/default/files/imce/covid19_dohanyzas_emmi_20200507.pdf [Letöltve: 2021. 04. 21.]

ERS Tobacco Control Committee (2019) ERS Position Paper on Heated Tobacco Products. A statement prepared by the ERS Tobacco Control Committee and approved by the ERS Advocacy Council, Science Council and Executive Committee. https:// www.ersnet.org/news-and-features/news/ers-position-paper-onheated-tobacco-products/ [Letöltve: 2021. 04. 20.]

European Lung Foundation (2020) E-cigarettes, heat-not-burn and smokeless tobacco products. https://breathe.ersjournals.com/ content/breathe/16/1/161ELF.full.pdf [Letöltve: 2021. 04 21.]

Jiang, Z., Ding, X., Fang, T., Huang, H., Zhou, W., Sun, Q. (2018) Study on heat transfer process of a heat not burn tobacco product flow field. Journal of Physics: Conference Series. 1064: 012011. DOI: 10.1088/1742-6596/1064/1/012011

Farsalinos, K. E., Yannovits, N., Sarri, T., Voudris, V., Poulas, K., Leischow, S. J. (2018) Carbonyl emissions from a novel heated tobacco product (IQOS): comparison with an e-cigarette and a tobacco cigarette. Addiction, Vol. 113. No. 11. pp. 2099-2106. DOI: 10.1111 /add. 14365 .

Foundation for a Smoke-Free World. (2018) Return of Private Foundation. https://www.smokefreeworld.org/sites/default/files/uploads/documents/fsfw_2018_form_990-pf_public_inspection.pdf [Letöltve: 2021. 04. 20.]

Glantz, S. A. (2018) Heated tobacco products: the example of IQOS. Tobacco Control, Vol. 27. pp. s1-s6. DOI: 10.1136/tobaccocontrol-2018-054601

Gupta, A. K., Nethan, S. T., Mehrotra, R. (2021) Tobacco use as a well-recognized cause of severe COVID-19 manifestations. Respiratory Medicine, Vol. 176. No. 106233. DOI: 10.1016/j. rmed.2020.106233

Johns Hopkins University. COVID-19 dashboard by the Center for Systems Science and Engineering (CSSE) at Johns Hopkins University (JHU). https://coronavirus.jhu.edu/map.html [Letöltve: 2021. 04. 20.]

Joó T. (2019) A dohányzás gazdasági hatásai. In: Kovács G. \& Horváth I. (eds) Dohányzás és leszokás - tudnivalók szakembereknek, érdeklődőknek. Medicina, Budapest. pp. 79-103.

Joó T., Szócska M., Vokó Z., Demjén T., Bodrogi J., Gaál P., \& Foley, K. L. (2018) The impact of anti-smoking policies of the 20102014 Hungarian government - a comprehensive evaluation. Tobacco Induced Diseases, Vol. 16. Suppl. 1. pp. 167-168. Paper: A440. DOI: $10.18332 /$ tid $/ 84756$

Joó, T., Vokó, Z., Bodrogi, J., \& Szócska, M. (2017) A dohányzás elleni küzdelem a 2010-2014 közötti időszakban. Interdiszciplináris Magyar Egészségügy (IME), Vol. 16. No. 10. pp. 11-17.

Kopa, P. N., \& Pawliczak, R. (2020) IQOS - a heat-not-burn (HnB) tobacco product - chemical composition and possible impact on oxidative stress and inflammatory response. A systematic review, Toxicology Mechanisms and Methods, Vol. 30. No. 2. pp. 81-87. DOI: 10.1080/15376516.2019.1669245

Koronavírus tájékoztató oldal (2020) https://koronavirus.gov.hu/elhunytak [Letöltve: 2021. 04. 21.]

Lal, P., Adam, D., Jones, A., et al. (2018) The Union's position on heated tobacco products. International Union Against Tuberculosis and Lung Diseases. https://www.theunion.org/what-we-do/
publications/official/body/Heated-Tobacco-Product-Union-Position-Statement-Final-25.01.18.pdf [Letöltve: 2021. 04. 21.]

Lee, A., Lee, S. Y., Lee, K. S. (2019) The use of heated tobacco products is associated with asthma, allergic rhinitis, and atopic dermatitis in Korean adolescents. Scientific Reports. Vol. 9. Article number: 17699. DOI: 10.1038/s41598-019-54102-4

Lempert, L. K., Glantz, S. (2020) Analysis of FDA's IQOS marketing authorisation and its policy impacts. Tobacco Control, Published Online First: 29 June 2020. DOI: 10.1136/tobaccocontrol-2019-055585

Magyar Tüdőgyógyász Társaság (2019) Az Egészségügyi Szakmai Kollégium Tüdőgyógyász Tagozat hevített dohánytermékekkel kapcsolatos állásfoglalása 2019. 11. 27. https://tudogyogyasz.hu/ News/News/28809 [Letöltve: 2021. 04. 21.]

Moazed, F., Chun, L., Matthay, M. A., Calfee, C. S., \& Gotts, J. (2018) Assessment of industry data on pulmonary and immunosuppressive effects of IQOS. Tobacco Control, Vol. 27. Suppl. 1. pp. s20-s25. DOI: 10.1136/tobaccocontrol-2018-054296

Országos Korányi Pulmonológiai Intézet (2019) Felnőtt Dohányzás Felmérés 2019. http://www.leszokastamogatas.hu/wp-content/ uploads/2021/03/Osszefoglalo_Felnott_Dohanyzas_ Felmeres_2019_1.4.pdf [Letöltve: 2021.04.21.]

Patanavanich, R., \& Glantz, S. A. (2020) Smoking is associated with COVID-19 progression: A meta-analysis. Nicotine \& Tobacco Research, Vol. 22. No. 9. pp. 1653-1656. DOI: 10.1093/ntr/ ntaa082

Ratajczak, A., Jankowski, P., Strus, P., Feleszko, W. (2020) Heat not burn tobacco product - A new global trend: Impact of heat-notburn tobacco products on public health, a systematic review. International Journal of Environmental Research and Public Health, Vol. 17. No. 2. pp. 409. DOI: 10.3390/ijerph17020409

Reddy, R. K., Charles, W. N., Sklavounos, A., Dutt, A., Seed, P. T., \& Khajuria, A. (2020) The effect of smoking on COVID-19 severity: A systematic review and meta analysis. Journal of Medical Virology, Vol. 93. No. 2. pp. 1045-1056. DOI: 10.1002/jmv.26389

Russo, P., Bonassi, S., Giacconi, R., Malavolta, M., Tomino, C., \& Maggi F. (2020) COVID-19 and smoking: is nicotine the hidden link? European Respiratory Journal, Vol. 55; 2001116. DOI: 10.1183/13993003.01116-2020

Shastri, M. D., Shukla, S. D., Chong, W. C., Kc, R., Dua, K., Patel, R. P., Peterson, G.M., \& O'Toole, R. F. (2021) Smoking and COVID-19: What we know so far. Respiratory Medicine, Vol. 176. No. 106237. DOI: 10.1016/j.rmed.2020.106237

Simonavicius, E., McNeill, A., Shahab, L., \& Brose, L. S. (2019) Heat-not-burn tobacco products: a systematic literature review. Tobacco Control, Vol. 28. No. 5. pp. 582-594. DOI: 10.1136/tobaccocontrol-2018-054419

St Helen, G., Jacob, Lii P., Nardone, N., Benowitz, \& N. L. (2018) QOS: examination of Philip Morris International's claim of reduced exposure. Tobacco Control, No. 27. pp. s30-s36.

Szócska, M., \& Joó, T. (2018) Health Security Issues. In: Finszter G. \& Sabjanics I. (eds) Security Challanges in the 21st Century. Springer. pp. 335-347. DOI: 10.1007/978-3-319-51761-2_25-1

UN. General Assembly (2011) Political Declaration of the High-level Meeting of the General Assembly resolution 66/2 on the Prevention and Control of Non-communicable Diseases resolution. Resolution adopted by the General Assembly 2011. https://digitallibrary.un.org/record/710899 [Letöltve: 2021. 04. 21.]

van Westen-Lagerweij, N. A., Meijer, E., Meeuwsen, E. G., Chavannes, N. H., Willemsen, M. C., \& Croes, E. A. (2021) Are smokers protected against SARS-CoV-2 infection (COVID-19)? The origins of the myth. Primary Care Respiratory Medicine Vol. 31. No. 10. DOI: $10.1038 / \mathrm{s} 41533-021-00223-1$

World Health Organization (2003, updated 2004, 2005) WHO Framework Convention on Tobacco Control. https://www.who. int/tobacco/framework/WHO_FCTC_english.pdf [Letöltve: 2021. 04. 21.] 
World Health Organization (2008a) Conference of the Parties of the WHO Framework Convention on Tobacco Control. Guidelines for the implementation of Article 5.3 of the WHO Framework Convention on Tobacco Control. Durban. https://www.who.int/ fctc/guidelines/article_5_3.pdf [Letöltve: 2021. 04. 19.]

World Health Organization (2008b) Tobacco industry interference with tobacco control. http://www.who.int/tobacco/publications/industry/interference/en [Letöltve: 2021. 04. 19.]

World Health Organization (2017a) Framework Convention on Tobacco Control Secretariat statement on the launch of the Foundation for a Smoke-Free World. https://www.who.int/fctc/mediacentre/statement/secretariat-statement-launch-foundation-for-asmoke-free-world/en/ [Letöltve: 2021. 04. 19.]

World Health Organization (2017b) WHO Statement on Philip Morris funded Foundation for a Smoke-Free World https://www.who. int/news/item/28-09-2017-who-statement-on-philip-morris-funded-foundation-for-a-smoke-free-world [Letöltve: 2021. 04. 20.]

World Health Organization (2019a) WHO global report on trends in prevalence of tobacco use 2000-2025, third edition. Geneva: World Health Organization. https://www.who.int/publications/ i/item/who-global-report-on-trends-in-prevalence-of-tobaccouse-2000-2025-third-edition [Letöltve: 2021. 04. 19.]
World Health Organization (2019b) WHO rejects collaboration with Philip Morris funded foundation. Bulletin of the World Health Organization, Vol. 97. No. 3. pp. 72-173. DOI: 10.2471/ BLT.19.010319

World Health Organization (2019c). WHO Report on the Global Tobacco Epidemic 2019: offer help to quit tobacco use. Geneva: World Health Organization. https://apps.who.int/iris/bitstream/ handle $/ 10665 / 326043 / 9789241516204-$ eng.pdf? ua $=1$ [Letöltve: 2021. 04. 19.]

World Health Organization (2020a) Smoking and COVID-19. Scientific Brief. https://www.who.int/news-room/commentaries/detail/smoking-and-covid-19 [Letöltve: 2021. 04. 21.]

World Health Organization (2020b) Heated Tobacco Products A brief. 2020. https://www.euro.who.int/_data/assets/pdf_ file/0008/443663/Heated-tobacco-products-brief-eng.pdf [Letöltve: 2021. 04. 21.]

World Health Organization (2020c) WHO statement on heated tobacco products and the US FDA decision regarding IQOS. https://www.who.int/news/item/27-07-2020-who-statementon-heated-tobacco-products-and-the-us-fda-decision-regardingiqos [Letöltve: 2021. 04. 21.]

A cikk a Creative Commons Attribution 4.0 International License (https://creativecommons.org/licenses/by/4.0/) feltételei szerint publikált Open Access közlemény, melynek szellemében a cikk bármilyen médiumban szabadon felhasználható, megosztható és újraközölhető, feltéve, hogy az eredeti szerző és a közlés helye, illetve a CC License linkje és az esetlegesen végrehajtott módositások feltüntetésre kerülnek. (SID_1) 